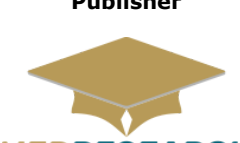

MEDRESEARCH

www.medresearch.in

\title{
Prevalence of respiratory illness among A.C users at Indore city: A case control analytical study
}

\author{
Jain C. ${ }^{*}$, Yesikar V. ${ }^{2}$, Dixit S. ${ }^{3}$, Rokade R. ${ }^{4}$ \\ DOI: https://doi.org/10.17511/ijphr.2016.i3.05
}

1* Chakresh Jain, Resident, Department of Community Medicine, MGM Medical College, Indore, Madhya Pradesh, India.

$\mathbf{2}$ Veena Yesikar, Associate Professor, Department of Community Medicine, MGM Medical College, Indore, Madhya Pradesh, India.

3 Sanjay Dixit, Professor \& Head, Department of Community Medicine, MGM Medical College, Indore, Madhya Pradesh, India.

${ }^{4}$ Rahul Rokade, Demonstrator, Department of Community Medicine, MGM Medical College, Indore, Madhya Pradesh, India.

\begin{abstract}
Background: In hot, humid climates air conditioners are not only a modern comfort but an essential element in getting through those sweltering, sticky days. But, like most modern conveniences, air conditioning also has its down-sides. Objectives: To know association between air conditioner users and respiratory illness 2.To know prevalence of respiratory illness in Air-conditioner users in comparison to non user. Material and methods: It's a Case-control study(Analytical study) case-Randomly selected 50 person of age group 25-50 yrs working in IDBI Bank, using AC were selected as case while Randomly selected 50 person of same age group working in NVDA Office who did not use AC at all served as controls. After Filling of Questionnaire \& Compilation of data and was analysied using MS Excel and SPSS. Result: $57 \%$ of A.C. user were using A.C. for $<3 y$ rs and $44 \%$ of them using for $>3 y$ rs. Most $(66 \%)$ of the people using ac at office time and $7 \%$ of them using continuously. $83 \%$ of A.C. users are not aware about necessity of cleaning of ac filters. cough/cold is significantly associated with ac use. (Calculated chi square $=5.54, \mathrm{P}<0.05=$ significant). Conclusion: cough/cold, Running nose \& Headache were significantly associated with Ac users. Findings were suggested that $A C$ users were more prone to mild respiratory illness while association between Skin irritation and $A C$ use is not significant.
\end{abstract}

Keywords: Air conditioners, Respiratory illness, Allergy

Corresponding Author

Chakresh Jain, Resident, Department of Community Medicine, MGM Medical College, Indore, Madhya Pradesh, India.

Email: drchakreshjain81@gmail.com
How to Cite this Article To Browse

Jain C, Yesikar V, Dixit S, Rokade R. Prevalence of respiratory illness among A.C users at Indore city: A case control analytical study. Public Health Rev Int J Public Health Res. 2016;3(3):119-124. Available From

https://publichealth.medresearch.in/index.php/ijphr/ article/view/41

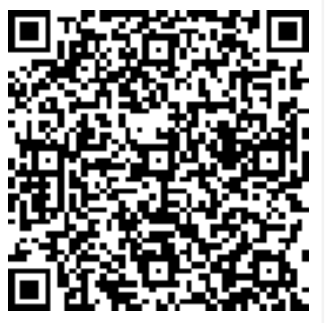

Manuscript Received 2016-06-08

Conflict of Interest No
Review Round 1 2016-06-20

Funding Nil

$\begin{gathered}\text { Review Round } 2 \\ \text { 2016-07-02 }\end{gathered}$
Ethical Approval
Yes

Review Round 2

Yes
Review Round 3

Plagiarism X-checker $5 \%$
Accepted 2016-07-17

(c) 2016 by Chakresh Jain, Veena Yesikar, Sanjay Dixit, Rahul Rokade and Published by Siddharth Health Research and Social Welfare Society. This is an Open Access article licensed under a Creative Commons Attribution 4.0 International License https://creativecommons.org/licenses/by/4.0/ unported [CC BY 4.0]. 


\section{Introduction}

These days' air conditioners (A.C) have a much improved technology and the basic principle in which it functions allows it to significantly improve the quality of the air. The air-conditioning system draws in outside air, filters it, heats, cools or humidifies it, circulates it around the building, then expels a portion of it to the outside environment. An air-conditioning system is made up of intake ducts, air filters, cooling tower/s, a boiler and exhaust ducts.

The air conditioner actually provides us with a much cleaner and safer air to breathe. People suffering from asthma \& allergic problems would also be benefited. Even for operations that are conducted in the hospitals, the air conditioner allows a climate where the infections can be controlled and the environment would be safe for the patients. However, air conditioning can also be held responsible for a few health problems like respiratory tract problems, infections \& Allergic reactions.

Chemical agents that are released into the environment from various anthropogenic activities impact human health seriously. The respiratory system is one major route whereby these chemicals and toxic agents enter the body and cause disorders, including mortality. On a global scale, millions suffer from respiratory ailments and other diseases attributed to the presence of toxic chemicals and biological agents in the air [1].

AC makes use of refrigerant materials like ammonia, non halogenated hydrocarbons like methane and works on principle of refrigeration cycle. They decrease the absolute humidity of air and make it dry. There is a cold condenser coil which condenses water vapours and this formed water can be removed by drain. Hence $A C$ makes the air cool and dry [2].

Air conditioners can be considered both as a boon and a bane, depending upon the circumstances. Let us consider the positive health implications of an air conditioner first.

Not only did air-conditioned operating rooms help those involved in surgery feel more comfortable, it also reduced "the risk of explosion of certain anesthetic gases [3].

However, air conditioning can also be held responsible for a few health problems.
If the central air conditioning system in an office or in a home is not properly maintained, then it can actually facilitate the spread of microorganisms. Contaminants from AC systems in commercial buildings may cause an immunologically mediated response in a substantial proportion of occupants [4].

Air conditioners are one of the main mould producing appliances at our homes it is because air conditioner is the most suitable place for fungus to grow due to the high density of moisture and dust inside [5].

Symptoms of mold allergies include: Sneezing, Chronic cough, Runny nose, Nasal congestion, Itchy, watery and red eyes, Skin rashes, Sinus headaches, reduced lung capacity and difficulty breathing. When air conditioning filters are clogged because they haven't been changed, the resulting poor indoor air quality can cause or contribute to the development of chronic respiratory diseases such as asthma, bronchitis and hypersensitivity pneumonitis.

It has been observed that hyperventilation of cold dry air causes bronchoconstriction in asthmatic patients. Cold dry air is what we inhale while using $A C$ 's; hence alteration in pulmonary functions may also be simulated in AC users [6].

There are three major categories of health problems:

01. Lungs and respiratory tract problemsrunny nose, blocked nose, coughing, sore throat, sneezing.

02. Virus and bacteria reactions- fever, chills, headaches, muscular ache, nausea and vomiting. Diseases includeinfluenza; bronchitis and Legionnaire's Disease

03. Allergic reactions- itchy nose, watering eyes, shortness of breath, wheezing and coughs. Illnesses include sinusitis, asthma and humidifier fever.

The body heat balance is determined by the surrounding air and radiant temperature, humidity air movement, clothing worn and the metabolic heat generated by human physical activity [7]. Freons primarily serve as propellants and are widely used in cooling systems Freon inhalations may lead to the production of cardiac arrhythmias. [8]. Increased severity of respiratory symptoms associated with air-flow resistance changes during cold air breathing [9]. 
Sick building syndrome (SBS), including eye, skin, and upper airway irritation, headache, and fatigue, is common in the general population and especially among women. SBS is known to be associated with exposure to heating, ventilation, and airconditioning (HVAC) systems, which are often present in modern offices. Exposure to HVAC systems in the workplace is a strong and significant risk factor for otorhinolaryngologist attendance and sickness absence in middle-aged women [10].

The greatest threat is from humidifiers which draw contaminated water from large and relatively stagnant sources and dispense it in nebulized form in forced air ventilation systems. The microorganisms probably originate from the ambient air itself, but proliferate on the nutrients of the water reservoirs [11].

\section{Methodology}

Present study is a Case-control study (Analytical study) which aimed to know association between air conditioner users and respiratory illness \& to know prevalence of respiratory illness in Air-conditioner users in comparison to non AC users. Randomly selected 50 employees of IDBI bank using ACs, of 25-50 years selected as case \& randomly selected 50 employees of Narmada Valley Development Authority (NVDA) office in Indore not using ACs, of same age group were selected as control. Inclusion criteria for both case \& control was chosen as age 25-50yrs \& those who were given informed verbal consent for part of the study.

Person who was not given informed consent, Person who smoke and drink, Person aged above 50yrs or below 25 years \& persons those who were chronically ill were excluded from the study. A wellstructured questionnaire was used in both groups to get the responses. The collected data were analyzed with the help of various tools and techniques to draw meaningful inferences and conclusion which were obtained using MS office Excel and SPSS. The study was conducted during March 2014 to June 2014.

\section{Results}

In present study randomly selected 50 employees of IDBI bank using ACs, of 25-50 years selected as case. Among these 50 cases 22(44\%) persons were using ACs >3years while $28(56 \%)$ persons were using $<3$ years of duration.
Out of these 50 cases $33(66 \%)$ subject were using AC for more than 8 hrs while $17(34 \%)$ were using ACs for $<8$ hrs a day. AC users were having different opinion on places of uses of $A C, 33(66 \%)$ employees were using Ac only office time, $8(16 \%)$ were use it when they required, 5 (10\%) peoples were using it at office \& home both while 4 ( $8 \%$ ) person are using $\mathrm{AC}$ continuously for all the time.

Only $9(18 \%)$ persons were having Knowledge about that if AC is not cleaned properly and regularly may produce ill effects while $41(82 \%)$ of AC users are not aware about necessity of cleaning of AC filters. Cough /cold, running/blocked nose \& headache like symptoms were found more prevalent among AC users compared to Non-users. Habit of consulting to doctors for these symptoms was more in $A C$ users.

Table-1: Prevalence of cough / cold in AC users and non-users

\begin{tabular}{|l|l|l|l|}
\hline \multicolumn{1}{|c|}{ Cough/cold } & \multicolumn{1}{c|}{ Ac users } & \multicolumn{1}{c|}{ Non users } & \multicolumn{1}{c|}{ total } \\
\hline Present & $37(74 \%)$ & $22(44 \%)$ & 59 \\
\hline Absent & $13(26 \%)$ & $28(56 \%)$ & 41 \\
\hline Total & 50 & 50 & 100 \\
\hline
\end{tabular}

- Degree of freedom $=1$

- Calculated chi square $=9.3, p$ value $=.002$

- $P<0.05=$ significant

- Cough/cold is significantly associated with ac use

Table-2: Prevalence of running/blocked nose in ac users and non-users

\begin{tabular}{|l|l|l|l|}
\hline \multicolumn{1}{|c|}{ Running nose/blocked nose } & Ac users & Non users & total \\
\hline Present & $12(24 \%)$ & $0(0 \%)$ & 12 \\
\hline Absent & $38(76 \%)$ & $50(100 \%)$ & 88 \\
\hline Total & 50 & 50 & 100 \\
\hline
\end{tabular}

- Fischer exact test is applied, $\mathrm{p}$ value $=.0002$

- $\mathrm{P}<0.05$ so significant.

- Running nose is significantly associated with ac use

Table-3: Prevalence of headache in ac users and non-users

\begin{tabular}{|l|l|l|l|}
\hline \multicolumn{1}{|c|}{ Headache } & \multicolumn{1}{c|}{ Ac users } & \multicolumn{1}{c|}{ Non users } & \multicolumn{1}{c|}{ Total } \\
\hline Present & $43(86 \%)$ & $32(64 \%)$ & 75 \\
\hline Absent & $7(14 \%)$ & $18(36 \%)$ & 25 \\
\hline Total & 50 & 50 & 100 \\
\hline
\end{tabular}

- Calculated chi sq. $=6.45$, $\mathrm{p}$ value $=0.01$

- $p<0.05$ significant

- Headache is significantly associated with Ac use 
Table-4: Prevalence of Skin irritation in AC users and non-users

\begin{tabular}{|l|l|l|l|}
\hline \multicolumn{1}{|c|}{ Skin Irritation } & \multicolumn{1}{c|}{ Ac Users } & \multicolumn{1}{c|}{ Non users } & \multicolumn{1}{c|}{ Total } \\
\hline Present & $4(8 \%)$ & $0(0 \%)$ & 4 \\
\hline Absent & $46(94 \%)$ & $50(100 \%)$ & 96 \\
\hline Total & 50 & 50 & 100 \\
\hline
\end{tabular}

- Fischer exact test is applied. $p$ value $=0.117$

- $P>0.05$, not significant.

- Association between Skin irritation and Ac use is not Significant.

\section{Discussion}

Present Study was done among the 50 Employees of IDBI bank working in AC environment for 6-8 hours/day who volunteered for the study \& employees of Narmada Valley Development Authority (NVDA) office not exposed to AC. Various processes of air conditioner systems like filtration, humidification, cooling, disinfection etc. it allows us very clean and safer air to breathe.

Air conditioned environment would be safe for the patients in operation theatres of hospitals also. However there is various health problems which might be arise because of air conditioners. If $A C$ is not properly maintained then it can lead to spread of microorganisms. The findings of Menzies [4] suggest that contaminants from AC systems in commercial buildings may cause an immunologically mediated response in a substantial proportion of occupants.

Up to now, published information on health risks of AC users is not very much in context of community or public health point of view. In this study when staff using $A C \mathrm{v} / \mathrm{s}$ those not using $A C$ were compared it was found that the Prevalence of running/blocked nose, cough/cold \& headache was more in AC users \& it was Statistically Significant.

Farah Khaliq et al [12] at University College of Medical Sciences \& GTB Hospital, Delhi done a study on young healthy subjects who were using AC's in their cars for at least one hour daily for a duration of 6 months, showed a predisposition of AC users towards respiratory dysfunction. Similarly a study done by Laxmikant J Borseet al [13] at D.Y. Patil medical college Pune, has shown that working in air conditioner environment causes impairment in respiratory functions which may lead to serious complications in future.

Savina O. Georgeet al [14] done a study at K. E. M.
Hospital, Mumbai \& found that the Respiratory Rate was significantly higher in Subjects using $A C$ at workplace compared to those not exposed to AC anywhere. R. Babitha et al [15] in a similar study on Bank employees found that there was a significant increase in the respiratory rate in the $A C$ exposed subjects. Decreased lung functions lead to the decreased oxygenation of the whole body and thus affect the body functions.

S.P. Choudhary et al [16] in Aurangabad done a study and revealed that AC car drivers had significantly reduced spirometry parameters when compared with age, sex and socio-economic status matched controls. Mohammed Jeelani et al [17] conducted astudy in Navodaya Medical College, Raichur, Karnataka\& results of their study shows a predisposition of AC users towards respiratory dysfunction. In present study one of the finding was the habit of consulting to doctors for symptoms like Cough /cold, running/blocked nose \& headache was more in AC users employees.

While in a study done by Mark J Mendell [18] stated that Reporting bias could artificially create the relationships seen, either by those in air-conditioned buildings reporting or seeking more doctor visits due to concern about health effects of $A C$, along with the reverse behaviours in those without $A C$, or by similarly biased reporting of ventilation type by those with and without doctors' visit. Findings of Mandell's study also supporting to findings of present study.

\section{Conclusion}

In today's modern lifestyle with raised living standards ACs use is not luxury but it's a necessity.Results of present study suggest that workers exposed to air conditioner environment may develop impairment in respiratory functions which may lead to serious complications in future. AC's and central AC systems can have a profound impact on quality of air we breathe but the technical, hygienic and microbiological feature of air intakes must be better insured in order to avoid the air intake becoming a risk component as regards contamination and indoor air quality.

\section{Reference}

01. Reducing risks, promoting health. Report. World Health Organization- Geneva. 2002.

Available at: [Article] [Crossref] 
02. Malcolm Jj. History of air conditioning. Newsweek Winter. 1997;130(24)42-4.

[Crossref]

03. Yaglou CP. Hospital air conditioning. J Am Med Assoc. $1938 ; 110(24) 2003-9$

doi: 10.1001/jama.1938.62790240003010. Available at: [Article] [Crossref]

04. Menzies D, Popa J, Hanley JA, Rand T, Milton DK. Effect of ultraviolet germicidal lights installed in office ventilation systems on workers' health and wellbeing- double-blind multiple crossover trial. Lancet. 2003 Nov $29 ; 362(9398) 1785-91$.

[Crossref]

05. Takano J. Does Your Air-conditioned Room Make You Sick?.

Available at: [Article] [Crossref]

06. Caire N, Cartier A, Ghezzo H, Malo JL. Influence of the duration of inhalation of cold dry air on the resulting bronchoconstriction in asthmatic subjects. Eur Respir J. 1989 Sep;2(8)741-5.

[Crossref]

07. Parsons, K. Human Thermal Environments. 2nd ed, Taylor and Francis- New York, NY, USA. 2003.

Available at: [Article] [Crossref]

08. Brady WJ, Stremski E, Eljaiek L, Aufderheide TP. Freon inhalational abuse presenting with ventricular fibrillation. Am J Emerg Med. 1994 Sep;12(5)533-6.

[Crossref]

09. Yuan-Ching Hseih, Regina Frayser, Joseph C Ross. The effect of cold air inhalation on respiratory gas exchange during exercise in patients with chronic obstructive pulmonary disease. Chest. 1970;57;18-21.

Available at: [Article] [Crossref]

10. Preziosi P, Czernichow S, Gehanno P, Hercberg S. Workplace air-conditioning and health services attendance among French middle-aged women- a prospective cohort study. Int J Epidemiol. 2004 Oct;33(5)1120-3.

[Crossref]

11. Hendrick DJ. Contaminated humidifiers and the lung editorial.

Available at: [Article] [Crossref]
12. Khaliq F, Sharma S, Tandon OP. Pulmonary functions in air conditioner users. Indian J Physiol Pharmacol. 2006 Jan-Mar;50(1)67-72. [Crossref]

13. Borse LJ, Yadav RD. Pulmonary Function Tests in Young Healthy Male Exposed To Air Conditioned Work Environment. International Journal of Health Sciences \& Research. 2012 Sept 35-6. Available at: [Article] [Crossref]

14. George SO. A Study Of Peak Expiretory Flow Rate In Air-Condition Users. International Journal of Basic and Applied Physiology. 2012;1(1)154.

Avaailable at: [Article] [Crossref]

15. Babitha R, et al. Pulmonary Function Tests in Air Conditioner Users. Journal of Clinical and Diagnostic Research. 2011 June;5(3)532-5.

Available at: [Article] [Crossref]

16. Choudhari SP, Doiphode RS. Study of Pulmonary Functions in Air Conditioned Car Drivers- A Cross-sectional Study. Journal of Dental and Medical Sciences. $2014 \operatorname{Dec}(13) 48-50$.

Available at: [Article] [Crossref]

17. Jeelani M, Ahmed MM. Effect of Air Conditioner on Pulmonary Functions in Healthy Males in and Around Raichur City. Journal of Evidence based Medicine and Healthcare. 2015;2(19)2816-21. Available at: [Article] [Crossref]

18. Mendell MJ. Commentary- air conditioning as a risk for increased use of health services. Int J Epidemiol. 2004 Oct;33(5)1123-6. [Crossref] 